\title{
Purple Silk and Black Cotton: Francisco Cabral and the Negotiation of Jesuit Attire in Japan (1570-73)
}

\section{Linda Zampol D’Ortia}

On September 10, 1573, Francisco Cabral (1533-16o9), superior of the Jesuit mission in Japan, informed the superior general in Rome (Francisco de Borja [1510-72], who had already died by that time) that the ship of Visitor Gonçalo Álvares $\left(15^{27}-73\right)$ had sunk in front of the port of Nagasaki, with immense loss of lives and funds. At least the state of the Japanese mission was finally acceptable:

Thanks to God's goodness, there is no small improvement [in the situation of the mission], especially in the matter of the silks, that the fathers wore, and the other luxuries they had, under the pretext that this was the better service of God and the preaching of his law; this was the cape that the devil was using to cover up the evils that [this practice] entailed. Now thanks to God's goodness they finally all wear clothes of black cotton with cassocks. ${ }^{1}$

Even if this might seem a small aspect of the missionary project in the archipelago, the contextualization of the change of clothes in the battle against the devil highlights the importance of the matter. The regulation of the garments worn by the Jesuits was in fact at the forefront of Cabral's missionary policy for the first years of his stay in the archipelago (1570-81), and appeared frequently in his correspondence. ${ }^{2}$

1 Cabral to Francisco de Borja, September 10, 1573, in Archivum Romanum Societatis Iesu (henceforth ARSI), JapSin 7, I, 166Av. Unless otherwise noted, all translations are the author's.

2 Considerations about what garments could be allowed in early modern Catholic missions were often found at the heart of the debates on missionary strategies. Notable examples of the use of a local dress by the members of the Society of Jesus include Matteo Ricci $\left(155^{2-}\right.$ 1610) in China, and Roberto de Nobili $\left(1577^{-1656)}\right.$ in southern India. See R. Po-chia Hsia. A Jesuit in the Forbidden City: Matteo Ricci, 1552-1610 (Oxford: Oxford University Press, 2010) and Sabina Pavone, "Spie, mandarini, bramini: I gesuiti e I loro travestimenti," Il capitale culturale 7 (2013): 227-43. 
This chapter will examine Cabral's attempts at policing Jesuit identity in Japan through the imposition of specific garments upon the missionaries. It will consider the importance assumed by dress in sixteenth-century Europe, and its relation to the attitude of Ignatius of Loyola (c.1491-1556) regarding the body and its modifications in the form of garments. It will consider how the use of silk garments by some Jesuits caused an internal division in the Japanese mission, highlighting Cabral's central role as he attempted to implement the orders of the visitor, who requested the end of the use and ownership of silk by the missionaries. He did so by refuting the motivations the missionaries produced to justify the use of silk garments, and by finding a niche in Japanese traditions that would make the policy alteration acceptable to the local converts. The chapter will then contextualize the complexities surrounding the use of silk garments in the larger understanding of what it meant, for Cabral, to be a Jesuit missionary in sixteenth-century Japan.

\section{Dress in the Society of Jesus}

Clothes have always been closely connected to the making of identity. Dress is defined in the seminal works of Mary E. Roach-Higgins and Joanne B. Eicher as "an assemblage of body modifications and/or supplements displayed by a person in communicating with other human beings." 3 It is a means that discloses information about the wearer, creating expectations in the interlocutors. ${ }^{4}$ These expectations are what made dress policy such a key element for early modern Jesuit missionaries.

Starting in the twelfth century, the changes introduced in the European production of garments (such as technological innovations, and the use of new materials), and the growing demand for shapes that fitted tighter to the body, led to the modification of the shape of clothes. This contributed to a gradual change in the understanding of the body: its social importance was augmented by dress, and this in turn led to the emergence of a close link between appearance and identity. ${ }^{5}$ Clothing therefore assumed a specific social weight: discourses

3 Joanne B. Eicher and Mary E. Roach-Higgins, "Definition and Classification of Dress: Implications for Analysis of Gender Roles," in Dress and Gender: Making and Meaning in Cultural Contexts, ed. Ruth Barnes and Joanne Eicher (New York: Berg, 1992), 15.

4 Ibid. See also Mary E. Roach-Higgins and Joanne B Eicher, "Dress and Identity," Clothing and Textiles Research Journal 10, no. 4 (1992): 1-8. Ruth Barnes and Joanne Eicher, "Introduction," in Barnes and Eicher, Dress and Gender, 1-7.

5 Ulinka Rublack, Dressing Up: Cultural Identity in Renaissance Europe (New York: Oxford University Press, 2010), 7, 16-18. 
on clothes were pushed to the forefront of the public arena by sumptuary laws. By the early modern period, garments acted as social shapers of the body, and were an integrant part of the identity of the wearer. ${ }^{6}$

In the case of religious people, the dress announced their separation from the world, and assumed a sacred nature by being "the external form of the religious." The body and the soul were considered permeable by the positive or negative characteristics ascribed to garments. ${ }^{8}$ Consequently, wearing clothes that were not considered acceptable for religious life could have worrying consequences. In the case of religious orders, the habit also physically indicated the belonging and affiliation of the wearer, becoming a tangible reminder of their identity. ${ }^{9}$

Influenced by attitudes developed between the twelfth and the fifteenth century, bright-colored garments assumed a negative characterization: they were forbidden to dignified people and considered at odds with Christian modesty. The black color, redeemed from its previous connection with sin, was now often found in clothing. From the eleventh and twelfth centuries, when the clergy had become the managerial structure of the new nation-states and the teaching staff of universities, the use of priestly black cassock and cape expanded to the secular world. University students wore similar gowns too. This practice led to the connection between black and professionalism, austerity, and virtue. The color's popularity was also linked to its prevalence in the Spanish court, which in turn influenced the fashion of European nobility and civic leaders. ${ }^{10}$

6 Alan Hunt, Governance of the Consuming Passions: A History of Sumptuary Law (Basingstoke: Macmillan, 1996), 7-13. Ann Rosalind Jones and Peter Stallybrass, Renaissance Clothing and the Materials of Memory (Cambridge: Cambridge University Press, 2000), 2-3.

7 Evonne Levy, "Jesuit Identity, Identifiable Jesuits? Jesuit Dress in Theory and in Image," in Le monde est une peinture: Jesuitische Identität und die Rolle der Bilder, ed. Elisabeth Oy-Marra and Volker R. Remmert, Beiträge zu den historischen Kulturwissenschaften, Bd. 7 (Berlin: Akademie Verlag, 2011), 137. Elizabeth Kuhns, The Habit: A History of the Clothing of Catholic Nuns (New York: Doubleday, 2003), 45.

8 Lesley K. Twomey, "Poverty and Richly Decorated Garments: A Re-evaluation of Their Significance in the Vita Christi of Isabel de Villena," Medieval Clothing and Textiles 3 (2007): 123 .

9 On material memory, see Jones and Stallybrass, Renaissance Clothing and the Materials of Memory.

10 Michel Pastoureau, Black: The History of a Color (Princeton, NJ: Princeton University Press, 2009), 95-98. John R. Harvey, The Story of Black (London: Reaktion Books, 2013), 97. John H. Munro, “The Anti-red Shift-To the 'Dark Side': Colour Changes in Flemish Luxury Woollens, 1300-1550," Medieval Clothing and Textiles 3, no. 1 (2007):55-98. 
This was the context in which Ignatius of Loyola lived: he spent the first twenty or so years of his life among courtiers and noblemen, and was certainly conscious of the social importance of dress. In his youth, he learned the significance of appearance for a religious person: even if he had received tonsure, he was refused clerical immunity during a trial, since he had never worn the appropriate clerical garments. ${ }^{11}$ When he decided to embrace the spiritual life, he gave away his rich colorful clothes to a beggar, and changed into sackcloth.

After moving to the University of Alcalá de Henares in 1526 , he preached and begged together with a group of "sack wearers." ${ }^{2}$ Their activity soon attracted the attention of the Inquisition. Suspicious of alumbrado activities, ${ }^{13}$ the inquisitors initially ordered Loyola's group to dye their garments different colors. Later, they changed the order to wearing the same clothes of the other students. ${ }^{14}$ Loyola obeyed, stating that clothing was of little importance. ${ }^{15}$ The student's black uniforms, similar to the clerical dress, stuck with Ignatius: after his first companions joined him, they would move through Paris and travel through French regions wearing the same garment. ${ }^{16}$

When it came to the composition of the Constitutions of the Society of Jesus, Loyola decided not to choose any specific habit for its members. Under the header of "What Pertains to Poverty and Its Consequences," it reads:

[577] The clothing too should have three characteristics: first, it should be proper; second, conformed to the usage of the region where one is living $[\mathrm{L}]$; and third, not contradictory to the poverty we profess, as would

11 James Brodrick, Saint Ignatius Loyola: The Pilgrim Years, 1491-1538 (San Francisco: Ignatius Press, 1998), 45-46.

12 John W. O'Malley, The First Jesuits (Cambridge, MA: Harvard University Press, 1993), 27.

13 The term alumbradismo indicates a broad spectrum of Spanish religious trends, considered heretical, and centred on interior, individual illumination. See Stefania Pastore, Un'eresia spagnola. Spiritualità conversa, alumbradismo e Inquisizione (1449-1559) (Florence: L.s. Olschki, 2004).

14 Luis Gonçalves da Câmara, "Acta S. Ignatii a P. Consalvo," in Monumenta ignatiana, ex autographis vel ex antiquioribus exemplis collecta: Scripta de sancto Ignatio de Loyola (Madrid: G. López del Horno, 1904), 1:71-4. Rafael M. Sanz de Diego, "Ignacio de Loyola en Alcalá de Henares (1526-1527)," in Ignacio de Loyola y su tiempo, ed. Juan Plazaola (Bilbao: Mensajero, Universidad de Deusto, 1992), 891.

15 Luis Gonçalves da Câmara, "Memoriale P. Gonsalvii," in Monumenta ignatiana, ex autographis vel ex antiquioribus exemplis collecta: Scripta de sancto Ignatio de Loyola (Madrid: G. López del Horno, 1904), 1:219-20.

16 O'Malley, First Jesuits, 32. Jean-Marie Glorieux, "Saint Ignace et la manière de se vêtir," Vie Consacrée 2 (1984): 117. 
happen through the wearing of silk or expensive clothes $[\mathrm{M}]$. These ought not to be used, in order that in everything humility and proper lowliness may be preserved, unto greater glory to God.

\section{[578] L. Or at least, it should not be altogether different.}

[579] M. This refers to those to whom the house gives clothing anew. But if those entering the house are wearing some expensive cloth or similar item, it does not forbid them. Further, if someone in some circumstance or necessity wears better but decent garments, it does not forbid him either; but these ought not to be used for ordinary wear. ${ }^{17}$

In another passage, it is stated that the function of clothing is essentially for "protection from cold and indecorum" (Cons. [297]), and that this purpose should always be kept in mind. A third rule refers to uniformity of clothing, among other things, as a tool to maintain unity among the members of the order (Cons. [671]).

Loyola therefore determined that the dress should be proper, in conformity with local use, and observant of the vow of poverty. The first feature is given in Latin as honestus, meaning respectable, dignified, or appropriate. In a similar vein, the second aspect reads as a suggestion to avoid any garment that would cause scandal. Lastly, the upholding of the vow of poverty represents the most important characteristic of the Jesuit clothing in usual circumstances, but equal importance is given to the practicality, and humanity, of the dress.

With an attitude that was common among religious founders, Loyola also did not describe the garments in detail, and never specified a color, a shape, or a material. At the same time, in his response to the 1554 condemnation by the University of Paris, he was adamant that the Jesuits should wear a specific dress, declaring that this should be the same cassock worn by the clergy of the region where they lived, and concluded that by wearing this dress, they would be able to carry out their duty to be everything to everyone. ${ }^{18}$

The Ignatian preoccupation with the appearance and external behavior of the Jesuits is also explicit in the Memorial (1555) written by Luís Gonçalves da Câmara (1519/20-75): "Modesty and external composure were very valued by

17 The Constitutions of the Society of Jesus, trans. George E. Ganss (St. Louis, MO: Institute of Jesuit Sources, 1970), 258. All the quotes from the Constitutions are taken from this edition.

18 "Responsio data decretum parisiensis," in Monumenta ignatiana part I: Epistolae et instructiones S. Ignatii (Madrid: Jesuit Historical Institute, 1911), 12:614-29. 
our Father in the members of the Society."19 Loyola believed that humility and manners would provide a good example and edification for both the Jesuits and the people with whom they came in contact.

Loyola therefore maintained some restrictions on the external appearance of the religious (the dress), just as he did on the external behavior of the Jesuits. The black cassock of the secular clergy fit with the requirements, since its color was understood as dignified and modest. No distinctive white collar was yet in use. A black beret cap, or biretta, was used as head cover in the house. ${ }^{20}$ The attire was common enough to avoid setting the Jesuits apart from the secular world, but it still permitted the recognition of the Jesuits performing an important social role. As Loyola himself noted, it fostered the sense of community, belonging, and solidarity of the Society, answering to a need for identification and uniformity. ${ }^{21}$

\section{Problems with Clothing in the Japanese Mission}

Considering these preoccupations regarding dress among Jesuits, it is not a surprise that the Asian headquarters of the Society, in Goa, became extremely worried when they received word that their brethren in Japan traded and owned silk. ${ }^{22}$ Up to the 156 os, the management of the Japanese mission had met with approval: India vice-provincial Melchior Nunes Barreto (1519/22-71) visited Japan in 1556 and described the mission to Superior General Diego Laínez

19 Câmara, "Memoriale P. Gonsalvii," 163. This attitude of Loyola appears in other episodes from his life (such as ibid., 241-42). A brief example of how Loyola's opinion on external composure (as described by Câmara) is reflected in the regulations of the Society is found in the Spanish critical edition of the Memorial: Luís Gonçalves da Câmara, Recuerdos ignacianos: Memorial, ed. Benigno Hernández Montes (Bilbao; Santander: Mensajero; Sal Terrae, 1992), 53-54.

20 Aside from this common dress, there were some local variations: for example, the Spanish assistancy's was a brown dress, except in Aragon, where they wore fine black robes until 1630. See Levy, "Jesuit Identity, Identifiable Jesuits?" 140, 144.

21 These aspects reflected the tension between the tendency to conformity and the push towards uniqueness, which is often found in early modern Catholicism. Ibid., 127; 140-41. See also Thomas M. McCoog, The Society of Jesus in Ireland, Scotland, and England, 15891597 (Farnham: Ashgate, 2012), 39-40.

22 For an overview of the history of the Japanese mission in these years, see M. Antoni J. Üçerler, “The Jesuit Enterprise in Japan (1573-1580)," in The Mercurian Project: Forming Jesuit Culture, 1573-1580, ed. Thomas M. McCoog (Rome: Institutum Historicum Societatis Iesu, 2004), 831-75. 
$(1512-65)$ in rather positive terms. ${ }^{23}$ The use of silk, according to Cabral, began around ${ }_{1564} / 65 .{ }^{24}$ In these same years, Cosme de Torres (1510-70), superior of the mission, was asking to be substituted, requesting a younger but experienced Jesuit for the task of returning harmony to the mission. ${ }^{25}$

In 1568, Cabral was nominated for the role. Born on the island of São Miguel to a family with noble origins, Cabral traveled to India in 1550 as a soldier at the orders of Viceroy Afonso de Noronha (in office 1550-54). At the end of 1554, he entered the Society of Jesus, where he held the positions of master of novices, and superior of the missions of Bazaim and Cochin. ${ }^{26}$ In 1568 , he was tasked by the father provincial Antonio de Quadros $(c .1529-71)$ to undertake a general visitation to the mission in Japan, to investigate and solve potential problems that the local superior could not solve on his own. Only, while already traveling, he was reached by the precise orders of Visitor Gonçalo Álvarez: to get rid of all the silks and the share the Jesuits had in the trade with Macao. ${ }^{27}$

When he reached Japan in 1570, Cabral's assessment of the mission was not positive. The first letter he sent after landing is lost, but in 1571 he described his work to both General Francisco de Borja ${ }^{28}$ and Diego Miró, who was at that time assistant of the Portugal assistancy in Rome. ${ }^{29}$ According to Cabral, at the outset of the mission, the first missionaries, Francis Xavier $\left(15^{06}-5^{2}\right)$, Cosme de Torres, and Juan Fernández (1526-67), endured a period of extreme poverty. The situation changed with the entry of Brother Luis d'Almeida (1556) into the Society:

[D'Almeida] brought four or five thousand cruzados, with which the trade and the dealings started, here in Japan as well as in China. With this abundance, this situation began to expand, together with the capital,

23 Barreto to Laínez, Cochin, January 15, 156o, published in Josef Franz Schütte, Monumenta historica Japoniae, vol. 1 (Rome: Monumenta Historica Societatis Iesu, 1975), 39-43.

24 Cabral to General Borja, Nagasaki, September 5, 1571, in ARSI, JapSin 7, I, 21r. The transcription is found in Pedro Lage Reis Correia, "Francisco Cabral and Lourenço Mexia in Macao (1582-1584): Two Different Perspectives of Evangelization in Japan," Bulletin of Portuguese-Japanese Studies 15 (December 2007): 47-77.

25 Torres to General Laínez, Kuchinotsu, October 20, 1565, printed in Schütte, Monumenta historica Japoniae 1:69-70.

26 For an overview of Francisco Cabral's life, see Alexandre Pelúcia, "Francisco Cabral," in Encontro Portugal Japão, vol. 3: Biografias (Lisbon: Grupo de trabalho do Ministério da Educação para as comemorações dos descobrimentos portugueses, 1994), 1-13.

27 Cabral to the superior general, Macao, November 20, 1583, in ARSI, JapSin 9, II, 187. The transcription can be found in Correia, "Francisco Cabral and Lourenço Mexia in Macao (1582-1584)."

28 ARSI, JapSin 7, I, fols. 2or-22v.

29 Cabral to Diego Miró, Nagasaki, September 6, 1571, in ARSI, JapSin 7, I, fols. 23r-24V. 
until seven or eight years ago when they started introducing silks and colored clothes and together with them the couple of servants they had now. As this required eating well and sleeping well, even the bed pillows and the cushions of some were made of silk and a father I saw even had a mattress in damask [...]. Father Baltasar da Costa went to welcome the incoming ship of the Portuguese [merchants], with many people accompanying him and he was wearing purple silk [...]. A Portuguese man went to embrace him [and] he put forward the fan he held in his hand and told him not to get close, because it would scandalize [the Japanese]. ${ }^{30}$

The first years of Cabral's stay in Japan were highly conditioned by the instructions given to him by Álvarez, and by the idea that his position would be temporary. While making clear that his hands were tied by Álvarez's orders, Cabral never suggested that he did not agree with the general gist of them. ${ }^{31}$ However, in his correspondence from Japan, he is mostly silent on the topic of the Jesuit practice of selling a share of the silk brought by the Portuguese merchants of Macao. Although he had been ordered to put an end to it, he never did. It is possible that he saw the trade as the only way to sustain the mission economically, and justified it as a service to God. ${ }^{32}$

Cabral, however, showed no doubt about the necessity to dispose of the silk clothing and to return to the black cassock that was in use in the Portuguese assistancy. To support his position, he stated that the colored silk clothes were not in accordance with the poverty and humility of the Society, and that the biggest part of the expenses of the mission was caused by this pomp. This behavior also prevented the good care of the Japanese Christians. ${ }^{33}$ To further back up his assertions, he referred to the example of the first fathers who had preached in Japan in absolute poverty, such as Francis Xavier, as the proper way of proceeding. However, he never mentioned the well-known episode in which Xavier changed his cassock for a silk dress to appear in front of the lord of Yamaguchi and obtain permission to preach. ${ }^{34}$

$30 \quad$ ARSI, JapSin 7, I, 23r.

31 Ibid., 21v.

32 However, years later, as provincial of India, he criticized the visitor Alessandro Valignano for not suppressing it. For more information on the silk trade debate, see Joseph F. Moran, The Japanese and the Jesuits: Alessandro Valignano in Sixteenth-Century Japan (London: Routledge, 1993), 119, 123.

33 ARSI, JapSin 7, I, 21r-23r.

34 Josef Franz Schütte, Valignano's Mission Principles for Japan. Vol. 1: From His Appointment as Visitor until His First Departure from Japan (1573-1582) (St. Louis: Institute of Jesuit Sources, 1980), 210. 
In the first general description Cabral wrote of the country, he also described Buddhist monks to the general, highlighting how "[their] habit is generally made of silk, but some [sects] are prohibited from wearing it and wear only cotton clothes or linen, of black or white color; even so, they are not less venerated than those that are loaded with silk." By mentioning this specific use, he was preparing the ground for his argumentation in favor of the black Jesuit cassock. ${ }^{35}$

Cabral perceived the refusal to change garments as coming from the mission at large:

I would not be able to describe to Your Paternity the work I had to do for this, and the temptations, because, aside from Father Cosme de Torres and Father João Baptista [de Monte], to whom also it did not appear a good thing, most [of the Jesuits] were against [changing clothes] and they told me that taking away the silks was to close the doors to the conversion of these lands because the Japanese only look at the exterior, as we did not wear silks. And if we wore black not only would no gentile lord pay us any attention, but not even the Christian converts, and other issues that were based on vanity and the excessive license that had been introduced. ${ }^{36}$

He was deeply troubled by the whole ordeal. He complained that Fathers Melchior de Figueiredo (1528-97) and Baltasar da Costa (c.1538-?) still used silks, and how, even in 1571, he had to destroy silk pillows, and a green sleeping gown made of Chinese damask; Father Organtino Gnecchi-Soldo (c.1530-16o9) also wrote to him opposing this reform. ${ }^{37}$

The lack of respect for obedience that the fathers were showing troubled Cabral deeply. As much as he lamented the poor state of the Japanese mission, and dearly missed his previous life in the college of Goa and in Macao (locations where Portuguese customs were the norm), ${ }^{38}$ he started working on rebuffing the various justifications that the missionaries presented to preserve their silk garments. He also spent much ink describing his work in detail, leaving behind a great deal of information on the rationale behind it. It is therefore possible to identify, from his letters, three situations in which the Jesuits would

\footnotetext{
35 ARSI, JapSin 7 I, 20v.

36 Ibid., 2or.

37 Ibid., 23v.

38 Cabral to unknown Father, Kuchinotsu, September 23, 1571, in ARSI, JapSin 7, III, fols. $36 \mathrm{r}-38 \mathrm{v}$.
} 
use garments that were not the standard black cassock: for Catholic rites that required special solemnity; for reasons of personal safety; and for reasons of prestige among the Japanese.

\section{The Dress Question in Japan: Church Rites}

With the growth of the communities of Christian converts, the Jesuits assumed the role of pastors of their flock during processions and special rites. ${ }^{39}$ They therefore had to represent the solemnity of the church's rites, and to present themselves accordingly. Rites that were deemed particularly important made use of silks and colors: in 1565 , Father Gaspar Vilela $\left(1_{526-72)}\right)$ headed a funeral procession in a red litter, donning a cape made of brocade. He was aware of the importance of the event, particularly for the impact it would make in the eyes of the non-converts, and used opulence to highlight the solemnity of the occasion. This tradition of grandiose funerals and memorial masses continued well into the seventeenth century. ${ }^{40}$

In his Historia de Japam, Luís Fróis (1532-97) was very careful to point out how the major glory of God was always behind this sort of behavior: on Vilela, he wrote that he was "intrepid and zealous for the honor of God and knew how important this [ceremony] was, since it was the first public funeral done with solemnity."41

Solemnity was considered a key element in baptisms too, and the accompanying ornaments were much appreciated by the Japanese. In 1581, Visitor Alessandro Valignano (1539-1606) recommended that the officiators should wear a surplice and a stole when officiating this rite. Organtino asked Gregory XIII (r.1572-85) to send ornaments made of brocade and velvet; in 1592, Valignano made a similar request, "either for the Society or for the bishop,"

39 "We are forced to spend all our life like secular clergy," lamented Valignano in his report on the Japanese mission, written to the general, October 27, 1580. Quoted in Alessandro Valignano, Sumario de las cosas de Japón (1583): Adiciones del sumario de Japón (1592), ed. José Luis Álvarez-Taladriz (Tokyo: Sophia University, 1954), 134*.

40 Evidenced by the memorial masses of some Christian noblewomen, such as Hosokawa Tama Gracia (1563-1600). Hélène Vu Thanh, "Between Accommodation and Intransigence: Jesuit Missionaries and Japanese Funeral Traditions," Journal of the LUCAS Graduate Conference 2 (2014): 121. See also Haruko Nawata Ward, Women Religious Leaders in Japan's Christian Century, 1549-1650 (Farnham: Ashgate, 2009), 235; 281-85; 324-25.

41 Luis Frois, Historia de Japam, ed. Joseph Wicki (Lisbon: Biblioteca Nacional Portugal, 1981), 2:104. 
signaling that the Jesuits were still covering the role of secular clergy ${ }^{42}$ Cabral himself is described as wearing a splendid cope during a sumptuous baptism ceremony in $1574 .^{43}$

It seems, therefore, that in keeping with both European and Japanese customs, ${ }^{44}$ starting from the beginning of the mission, the use of luxurious items and clothing on special religious occasions was widespread. Even if Cabral's intent was to eradicate all luxury, he never censored this aspect of the Jesuits' activity. The fact that he himself was part of a rite that made use of expensive instruments, decorations, and garments suggests that he comprehended and accepted both the role of the Jesuits as secular clergy, and the deep connection between luxury and sanctity that was found in both Japanese and European traditions. He probably allowed this use in the understanding that it was done for reasons of edification, and ultimately for the glory of God.

\section{Dress Question in Japan: Safety}

The second reason that supported the use of luxurious clothes stemmed from a fear for the personal safety of the missionaries. In the initial years after the establishment of the mission, Japan was in a continuous state of war. The roads were often unsafe, and the political situation was very unstable. This frequently left the missionaries with no other solution than to escape the turmoil, leaving behind their communities of converts and most of their belongings.

Very soon the Jesuits started following the practice of disguising themselves as poor traveling monks. In 1559, Father Vilela, Brother Lourenço of Hizen (1525/26-92), and a dōjuku (lay auxiliary) named Damião (c.1536-86), moved to Miyako (Kyōto) to found a new mission. According to Frois, they traveled "like it is customary in the land, with shaved heads and beards, wearing their poor kimono." 45 He did not mention any specific feature of the kimono worn by the group, except for it being described as poor. This need for safety was one of the reasons given to Cabral to persuade him to change into local garments.

42 Jesús López Gay, "La liturgia en la misión del Japón del siglo XVI," Studia missionaria 4 (1970), 93-94.

43 Frois, Historia de Japam, 2:415.

44 Jesuit descriptions of Japanese funerals, with specific attention given to the clothes of the monks officiating, can be found in López Gay, La liturgia en la misión del Japón del siglo XVI, 197-208.

45 Luis Frois, Historia de Japam, ed. Joseph Wicki (Lisbon: Biblioteca Nacional Portugal, 1976), 1:137-8. 
Describing his visit to Miyako in the previous year, ${ }^{46}$ on September 23,1572 , he wrote to Quadros, provincial of India:

They tried to frighten me and importuned me with reasons to change my dress, and leave behind the cassock and the cape, and cover my cap [corona] so that I would save my life [by being] anonymous. ${ }^{47}$ But since I already had experienced fears and difficulties that other times had been fantasies of uncertain [desconfiada] people, I trusted God, who can make fierce lions meek as lambs when he so wishes, and the virtue of the holy obedience which was the reason why I was undertaking that voyage; I decided that neither I nor the brother would change the garments of the Society, and so without any silk or insignia of monk, we went on our voyage, always declaring myself a father of the Society, even if unworthy. And my hope was not misguided, and when we boarded the ship, we started feeling the Lord's mercy, because not only the sailors and the heathen passengers did us no offense, but they treated us with politeness and courtesy. ${ }^{48}$

Cabral explicitly mentioned silk clothes when speaking of travel in disguise, in opposition to the poor travel kimono used by Vilela in 1559. Since this is a date antecedent to the beginning of the use of silks, it is possible that they were introduced over time, both as domestic garments and as traveling clothes. There is in fact no mention of the poor kimono for traveling in any of Cabral's letters.

In a letter written some days earlier, Cabral had explicitly explained his strategy: "I trust in God Our Lord that with his help I shall work and he has to grant me to be a true servant of this holy Society of Jesus." 49 This topic of being a "true Jesuit" to obtain divine favor was touched on again in another letter:

As for news about me, I have recently come back from Miyako, where God Our Lord gave me so many mercies that I cannot emphasize them

46 See also Frois, Historia de Japam, 2:357-65.

47 Together with the black cassock and a collar, the Jesuits of the Indian province did not wear a biretta, but instead "a kind of cap which resembled in form a hat from which the brim had been removed." It is possible that Cabral is speaking about such a head cover. Charles J. Borges, The Economics of the Goa Jesuits, 1542-1759: An Explanation of Their Rise and Fall (New Delhi: Concept, 1994), 31-32.

48 Cabral to Antonio de Quadros, Nagasaki, September 23, 1572, in RAHм, Cortes, 9/2663, 85 r-v.

Cabral to Juan Batista de Ribera, Nagasaki, September 19, 1571, in ARSI JapSin 7, I, 95r-v. 
more, because, even if they frightened and alarmed me with great concerns, [telling me] it was necessary to change the dress and travel anonymously with silk clothes, I nevertheless wanted to travel more confident in God and in the obedience for which I was doing that travel, than in the [earthly] means they gave me; so I went with my cassock and my cap, calling myself, in all kingdoms and lands I passed, a father of the Society of Jesus, and preaching his name through a Japanese brother who was coming with me; not only when going, but also when coming back, no peril they had foretold happened, but in this manner the shōgun and [Oda] Nobunaga and all the great lords of those parts gave much honor and favors to me, who was dressed so poorly, that all the Christians and heathens were surprised; some noblemen converted, and many others too, and they asked for preaching from many places. ${ }^{50}$

These passages show how Cabral adamantly refused the reason of personal safety as a valid concern. Even if he always mentioned the fact that the monks' robes were made of silk, their luxury here is not the problem: when it comes to travel, according to Cabral, it does not do to disguise oneself, no matter if the disguise is generic (silk) or a more specific one (insignia of a monk). The proper way to travel, for a Jesuit, was to announce himself as such, and to preach the name of Jesus Christ, without fear.

While Cabral thanked divine Providence for the lack of accidents during his voyages, he also forged a more direct connection between the clothes he was wearing and God: "I nevertheless wanted to travel being more confident in God and in the obedience for which I was doing that travel, more than in the means they gave me." His refusal to wear silk clothes, and to keep wearing his cassock, was presented as a direct proof of his faith. He strongly implied that Oda Nobunaga (1534-82) and the shōgun, as well as all the other noblemen, honored him thanks to his clothes and not despite them; this perspective was made explicit also in his 1593 letter to Claudio Acquaviva (1543-1615): "And God Our Lord helped with [the change of clothing], so that immediately his law started to gain reputation. The fathers were honored more by king $[\mathrm{s}]$ and lords of Japan when they were dressed with black cloth cassocks, than when they wore silk clothes and carried all that paraphernalia." ${ }^{51}$ Divine favor was also the cause of the many conversions (as was the kindness of other travelers: "we started feeling the Lord's mercy").

5o Cabral to a man outside the Society, Kochinotsu, September 29, 1572, in ARSI 7, III, 99 r.

51 Cabral to Acquaviva, Cochin, December 15, 1593, printed in Joseph Wicki, Documenta Indica XVI (1592-1594) (Rome: Monumenta Historica Societatis Iesu, 1984), 546. 
In Cabral's opinion, therefore, the Jesuit practice of traveling while dressed as monks was indicative of a lack of faith in God and in holy obedience (and therefore in the Society). Moreover, this attitude was particularly alarming since it took the shape of a dangerous nicodemism, both when refusing the cassock, and when using a monk's attire. For Cabral, this camouflaging would also push the Jesuit asunder from the Society's origins and core, which were central to their ministries. Instead, the way to show faith was to declare oneself openly as a Jesuit by dressing like a Jesuit. In doing so, one could become "a true servant of this holy Society of Jesus"; that is, be a Jesuit. Conversions, and a successful mission, would then follow. ${ }^{52}$

\section{Dress Question in Japan: Prestige}

This point of view is further clarified by the last instance in which the Jesuit would use silk clothes: prestige among the Japanese. This was articulated through two different but correlated aspects: prestige in the larger community, and prestige among the higher classes. Regarding the former, Cabral related a test he did in 1572 in the city of Sakai:

Father Organtino and the Japanese brother Lourenço came to visit me dressed in silks. Before changing clothes, they gave me some reasons, even [telling] me that we should not change: summarizing these reasons, the hindrance it would be to the growing of Christendom for the ridicule they would subject us, since we wore a more vile habit than their monks; but since I had experience that these were human fears and wrong persuasions, I wanted to see how many stones they would throw at me, so I went out in the streets of Sakai to sightsee, with my cotton clothes, and Brother Juan in the same way; Lourenço came with us with his silk dress, while Father Organtino stayed in the house. And walking through the main streets of the city, only in one some children followed me, without

$5^{2}$ The maintenance of the spirit of the Society as one of the keys for successful missions was not just Cabral's interpretation; Câmara, for example, was of the same opinion, as can be seen in one of his letters to Nadal: "Many souls depend on [the Portuguese province], as many as are in the East, to whom nothing lacks to convert, except to send from here many people well taught and brought up in the spirit of the Society." Joseph Wicki, Documenta Indica $V(1561-1563)$ (Rome: Monumenta Historica Societatis Iesu, 1958), $18^{*}$. 
doing anything worse than looking at me as if frightened by a new thing, and sometimes they would call me Deus (Dios) [God]. ${ }^{53}$

This was a very limited examination, since Sakai had an established Christian community and was relatively safe, but it was enough to convince Cabral that the Japanese would not ridicule the fathers in the streets, and conversions would not suffer. Cabral also conferred with some honored Christians:

I asked for advice from the owner of the house [where Cabral was staying] (who is the most important Christian of Sakai) about the change of our clothes, asking him to clarify to me if maybe he felt that using our cassocks and capes without any silk would be of any impediment, because they are so alien to our vows; he replied that he thought it very good, that we dressed like priests and, although in the beginning it would be a novelty to some, later everybody would think it good. After three or four days, some of the most important citizens of Sakai, among whom a Christian, came for a banquet [...]. After giving some explanations, they concluded that it was very well done. ${ }^{54}$

After speaking with some of the local leaders, ${ }^{55}$ therefore, and testing his clothes on the streets of Sakai, Cabral came to the conclusion that the assumption that they might lose their reputation had no real foundation. He attributed it to misgivings and lack of faith ("human fears"), as he had done with the concerns about safety.

The Jesuits seem more interested in describing what was scandalous or curious in their eyes than what was actually worn, and the surviving descriptions of clothes are vague at best. Cabral especially tended to refer to the clothes worn by his brethren as "the silk garments," "the silks," "colorful silk clothes." It is therefore difficult to understand what exactly the missionaries were wearing. One of the few descriptions in Cabral's letters that offers some detail is the

53 Cabral to Antonio de Quadros, Nagasaki, September 23, 1572, in RAHM, Cortes, 9/2663, gor-v.

54 Ibid., 9or.

55 Among these leaders there was Sancho Sangadono, head of the Shirai family who served in the fortress of Iimori, and was one of the oldest converts of the country. Maria Grazia Petrucci, "Pirates, Gunpowder, and Christianity in Late Sixteenth-Century Japan," in Elusive Pirates, Pervasive Smugglers: Violence and Clandestine Trade in the Greater China Seas, ed. Robert J. Antony (Hong Kong: Hong Kong University Press, 2010), 67-69. 
outfit worn by Father Baltasar da Costa in an infamous incident. Dressed lavishly during the welcoming of the yearly carrack, in front of the Christian community of Nagasaki, Costa failed to impress both the Portuguese and his superior. The Jesuit was described as wearing a "vestido de seda roxa" (dress of red silk) and carrying a fan; nothing is said of the shape of the dress. ${ }^{56}$ This is possibly the only case in which Cabral mentioned the specific color of the garment he was discussing: purple. ${ }^{57}$

Cabral seemed to find this incident particularly worrying, since it represented everything he held against the use of silk garments. Not only was a priest of the Society dressed in a material explicitly prohibited in the Constitutions (Cons. [577]) but it was also a colorful garment, in a way that was not proper at all. A fidalgo (member of the gentry) like Cabral must have been familiar with the importance of somber colors to display austerity and virtue, and with the permeability of the soul in relation to the clothes that covered the body. The color purple might have been particularly offensive, being specific of the garments of bishops, and also a liturgical color. A Jesuit wearing a purple silk garment could not be, in Cabral's eyes, a Jesuit at all, and he would not jeopardize the integrity of the Society for a lesser concern such as social prestige.

The second aspect regarding the prestige among the Japanese was related to the Jesuits' relationship with the higher classes. Francis Xavier had learned very quickly that Japanese lords would not grant him audience unless he presented himself as respectable enough in their eyes. Considering the need for official authorization and formal support from the authorities for preaching, and Cabral's own top-down strategy for conversion, without audiences there would be no way of proselytizing. 58

On this topic, Frois gave a description of the dilemma the fathers of Miyako had to face in the first years of the mission there:

$5^{6}$ Cabral to Diogo Mirão, September 6, 1571, Nagasaki, in ARSI, JapSin 7, I, 23 r.

57 While some doubts can arise regarding the actual hue of the color roxo in Japan in the sixteenth century, in the 1595 Dictionarium Latino-Lusitanicum, ac Iaponicum, the entry "Violaceus-a-um" read "roxa ou de cor de violeta, murasaki o naru mono," therefore "roxo or violet" in Portuguese, and "purple" in Japanese. João Rodrigues also translated shie 紫衣 [Buddhist purple robe] as "vsam de roxo" (quoted in Alessandro Valignano, Il cerimoniale per i missionari del Giappone, ed. Josef Franz Schütte [Rome: Edizioni di Storia e letteratura, 1946], 328-89).

$5^{8}$ In his letter to the general, he explicitly said that the feudal lords were their best apostles. ARSI, JapSin 7 I, 2 or. 
Aside from the ordinary obligation that existed [to visit the shōgun for the New Year], the heathens could not understand the law of God, nor regard with esteem the fathers, if they saw them defrauded or excluded from this visitation that is so honorable and solemn to them. And also because the Japanese commonly do not esteem foreigners more than their exterior and the dress they wear, because even the monks in these days work to make a great display of themselves: therefore, the old Christians of Miyako, whose expertise the father [Gaspar Vilela] had to follow, insistently begged the fathers to allow as much flexibility as possible in the clothes, since these great lords were proud, and would be affronted and insulted if the fathers had appeared in front of them with common and ordinary clothes; [good clothes] would reflect better credit and reputation on the Christians, at least in those initial origins, when the gentiles did not know yet the dignity of the clergy and of Christian religion..$^{59}$

As stated above, at this time the Miyako mission did not have enough funds to buy silk Japanese clothes, so Vilela apparently used what they already had: clerical vestments. For his first visit to the shōgun, he wore a surplice and a stole; then a mantle and a new cassock of Portuguese cloth. For his third visit, in 1565 , he wore a loba aberta (open cassock) made of camlet, an old cope with orphreys, made of brocade, and his hat. On this same occasion, Frois wore a mantle, a cassock, and Chinese slippers of twisted sewing silk. ${ }^{60}$

Once extreme poverty was overcome, it seems the Jesuits preferred to use local clothes, and their choice fell on silk kimono. It is possible that they were later prompted to use silks every day, instead of only when visiting influential people, because "[good clothes] would reflect better credit and reputation on the Christians." This would explain the diffuse use of silk in daily situations and during travel, especially in the mission of Miyako.

The monks were apparently taken as models to follow to forge the missionaries' new identities, and to calibrate their behavior. When they understood that "even the monks in these days work to make a great display of themselves," the solution they adopted was not to dress like a monk, but to wear European garments that the Jesuits hoped would help achieve the same result. When references to direct adaptations are found, they are presented as a form of disguise.

\footnotetext{
59 Frois, Historia de Japam, 2:13.

6o Ibid., 13-14.
} 
As mentioned above, Cabral also personally visited both the shōgun and Nobunaga; on both occasions, he was very careful to follow Japanese etiquette, declaring himself a "good cortesano [courtier]." Nobunaga (who had his retinue dressed in rough clothes instead of silk) was interested in their change of clothing and seemed to be happy with the explanation given: that these were the clothes their order wore in India and now it was not necessary to wear silk because they were well known in Japan too. After this meeting, Cabral was certain that the Japanese lords would not object to any change of clothing, and considered the matter closed on all fronts. ${ }^{61}$

\section{Missionary Policy and Jesuit Dress}

After this initial period of discussion, the missionaries accepted the change, if not necessarily wholeheartedly. The modifications made to the mission policies by Valignano, at the end of the 1570s, maintained the spirit of the decision, even if he regulated the use of clothing in more detail. ${ }^{62}$ The use of silk was resumed only with the beginning of the persecutions in 1588 , on grounds of safety, ${ }^{63}$ and various disguises were used until the end of the mission. ${ }^{64}$

Following the orders coming from India, Cabral had decided that the silks used by the missionaries should be banned, in keeping with the rules of the Society of Jesus and, possibly more importantly, with the practice of using the black cassock, implemented in the Indian province. Regardless of the Constitutions' openness to adaptation, Cabral believed that the cassock was too important a part of Jesuit identity to be disregarded. The obedience due to his superiors, and the need of divine grace for the conversions, sealed his opinion. The resistance he met from his brethren, however, obliged him to deal with the question extensively, considering it from various points of view.

Silk clothing was not part of the Jesuit identity that Cabral was familiar with, in the same way as it was not part of any Catholic order that professed a vow of

61 The visit is described in Cabral's letter to Antonio de Quadros, Nagasaki, September 23,

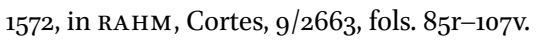

62 Valignano, Sumario de las cosas de Japón, 231-32.

63 At least in Miyako, as Organtino informed his confrères in his letter to the priests and brothers in Hirado, Miyako, November 25, 1588, printed in Cartas que os padres e irmãos da Companhia de Iesus escreuerão dos reynos de Iapão e China (Évora: Manoel de Lyra, 1598), 2:225v-31v.

64 The missionaries dressed as Portuguese merchants, Buddhist monks, or Japanese laymen, as described in Matteo Couros's letter to the general, Nagasaki, February 25, 1618, in Schütte, Monumenta historica Japoniae 1:773. 
poverty. Even more important, Cabral saw the respect of the Jesuit way of proceeding, and faith in God, as the basis for the missionary policy for Japan, since it was the only way to obtain God's favor. Believing that conversion was a matter of divine intervention on the hearts of the Japanese people, he considered earthly matters decidedly less important.

However, instead of simply banning silk on these grounds, Cabral elaborated his response to the problem considering the objections to the black cassock. The matter of safety was barely dignified with an answer, since he considered it a problem for lesser men who lacked faith. Against the point that poor clothes would be a hindrance to conversion, he had two replies: the first was that some Japanese monks wore black cotton and they were respected just like the others, so there would be no scandal if the Jesuits adapted to this tradition and, following the Constitutions, "conformed to the usage of the region where [they were] living." In this instance, he did not reject adaptation per se, but provided a solution by giving an alternative (if self-serving) interpretation of the same culture, finding a secondary tradition that could be used to bridge the distance between the Japanese monks' garb and the Jesuit cassock. Secondly, since he was also aware of the possibility of offending the key people in the conversion of the country, he confirmed with them that this was acceptable, moving in a cautious way to avoid scandal.

In delineating his policy, Cabral shows his proximity to the Ignatian understanding of the body and its modifications. He preserved the flexibility of the way of proceeding, by demonstrating an awareness of the context in which he operated. At the same time, his ability to accommodate was severely restricted by Portuguese Jesuit customs regarding clothing, which he was set to follow. He finally solved the problem by finding a space to negotiate between Jesuit European customs and Japanese traditions. His ability to find a compromise was successful in the sense that his guidelines left their mark on subsequent missionary policies that were adopted in Japan: they persisted through radical changes, and were abandoned only under the duress of the persecutions. 